\title{
ABORTION LAW IN ETHIOPIA: A Comparative Perspective
}

\author{
Tsehai Wada*
}

\section{Introduction}

Induced abortion or the deliberate termination of pregnancy is one of the most controversial issues in legal discourse. As a legal issue, abortion is usually discussed in light of the principles of criminal law. Depending on circumstances, however, abortion can also be discussed from the standpoint of constitutional law. In the former case, the issue usually takes the form of criminalizing or decriminalizing the act, while in the latter, the issue becomes whether a pregnant woman has a constitutional right to terminate her pregnancy. The issue thus usually involves the competing arguments in favour of the "right" of the fetus to be brought onto life (i.e. personhood) vis-à-vis the right of the mother to abortion based on her interests and choice.

Although many factors have contributed to the debate, it appears that religious outlooks permeate the controversy pertaining to criminalizing and decriminalizing abortion. Major religions still hold that abortion is the deliberate taking away of life and, therefore, not condoned under any circumstance. On the other side of the spectrum, advocates of women's rights, argue that when the interests of the fetus comes into conflict with the rights of the pregnant woman, the latter should take precedence and it is the woman's decision that should count in the end.

The issue whether a fetus has a life of its own that is worthy of protection under the law, is found to be another issue of contention. Some argue that a fetus has no life of its own for some weeks while others contend that life starts from the very moment of the union of the sperm and the egg, which according to this view is a scientific truth. One of the major aspects of the debate on abortion is the mindset of these perspectives of thought influenced by different values.

Abortion is an issue, which affects every country in the globe. In countries that have decriminalized abortion, women are spared of the dire consequences of illegal abortion. In many other countries wherein abortion is a criminal act, however, illegal abortion is the major cause of maternal mortality and other serious health problems, as is to be discussed at a later stage.

${ }^{*}$ LL.B, LL.M; Assistant Professor of Law (Faculty of Law, Addis Ababa University) 
Given the nature of abortion as an act as well as a point of debate, the issue deserves discussion from a comparative perspective.

This article attempts to shed light on the historical development of the laws of various countries and the effects of illegal abortion in many countries. Religious positions are the main catalysts that fuel the debate on abortion, and the article will thus attempt to highlight the positions of some of the major religions.

Ethiopia's legal regime pertaining to abortion has been changing through time. In 2004, Ethiopia has enacted a new Criminal Code that has radically (albeit inadequately) reversed the highly restrictive position of previous laws on abortion. The process had involved a lively and heated public debate on the pros and cons of criminalizing / decriminalizing abortion. In addition to changes in the law, therefore, the debate has enhanced public awareness and concern over the issue. Thus, the new law and the setting of public discourse which accompanied its enactment will definitely influence the conduct of many individuals including pregnant women, physicians, illegal abortionists, etc. for the years and decades to come. This article, therefore, attempts to show the nature of the debate and critically examines whether the new law has appropriately and adequately addressed the issue.

This article encourages readers towards informed judgment rather than polarized recriminations. ${ }^{1}$ The first and second sections of this article discuss the history of abortion and the positions of major religions on abortion. The third section addresses the legal regime and its impact in various countries. And the last three sections deal with Ethiopia's abortion law and the public debate that surrounded the 2004 Criminal Code, followed by conclusions and recommendations.

\section{The History of Abortion}

Abortion is not a recent phenomenon but a practice that is at least as old as recorded history. "The oldest known medical texts citing abortion techniques appeared in China around 2737 B.C.E., more than 4,700 years ago". ${ }^{2}$ Such practices are older than recorded history...even among indigenous cultures. ${ }^{3}$

\footnotetext{
1 Note: nomenon is peculiar to those who are living Anti-abortionists in Ethiopia attempt to in cities, the educated, the 'uncultured', etc. show that the major causes of unwanted ${ }^{2}$ Ivan R. Dee, Born Unwanted, 10, in D. P. pregnancy and thus abortion are, lack of Judges, Hard Choices, Lost Voices, religious discipline, immorality and the in- (Chicago, 1993). (Hereafter, Judges) at 84 fluence of alien culture, or generally break- ${ }^{3}$ G. Devereaux, A Study of Abortions in down of cultural and religious values, etc. Primitive Societies (New York, 1955), in They also attempt to show that the phe- Judges, at 85
} 
Moreover, figures on distribution and frequency [of abortion among tribal cultures] suggest that the practice of voluntary abortion is and has been a common practice in a majority of cultural traditions of mankind. ${ }^{4}$

Abortion was practiced in classical Greek and Roman times during which traditional beliefs, Judaism and Christianity eventually shared the outlooks of Hebrew, Greek, and Roman thoughts which believed that feticide was not homicide prior to the fetus forming. ${ }^{5}$ Socrates, Plato and Aristotle were known to have been supporters of abortion. Aristotle wrote that "when couples have children in excess, let abortion be procured before sense and life have begun; what may or may not be lawfully done in these cases depends on the question of life and sensation."6 Even Hippocrates, who was against abortion because he feared injury to the woman, recommended it under certain circumstances by prescribing violent exercise. ${ }^{7}$

Greek and Roman civilizations considered abortion an integral part of maintaining a stable population ${ }^{8}$. According to Soranus, [circa 98-138 A.D.]; abortion was practiced to conceal the consequences of adultery, to maintain feminine beauty and to avoid danger to the mother when her uterus is too small to accommodate the embryo. ${ }^{9}$

In primitive tribal societies, abortion was induced by using poisonous herbs, disrupting the fetus or by sheer pressure on the abdomen until vaginal bleeding occurred. ${ }^{10}$ It should, however, be noted that all scholars are not in agreement with the assertion that abortion was practiced with impunity by all ancient societies. Some have maintained that "the ancient Persians and Assyrians punished abortion .... and the Code of Hammurabi (c. 1728 B.C.E.) and the Septuagint version of the Book of Exodus. Both texts, however, addressed only the unintentional causing of an abortion by a third party." 11

\footnotetext{
${ }^{4}$ H. L. Shapiro, “ An Anthropologists View” in Abortion in a Changing World, 1:184, in Judges, Supra, Note 2 at 85.

${ }^{5}$ J. M. Riddle, Contraception and Abortion from the Ancient World to the Renaissance (Cambridge, Mass., 1992), 20-23, in Judges, at 86.

${ }^{6}$ Aristotle, Politics (Circa 350 B.C.E) Book Seven, Part XVI. Paragraph 5, Translated by Benjamin Jowett)

${ }^{7}$ H.P. David, "Abortion Policies", in Abortions and Sterilization: Medical and Social Aspects, J.E. Hodgson, ed. Grun and Stratton, New York, 1981, pp.1- 40, and Wendell W. Watters, Compulsory Parenthood: The

Truth About Abortion, McClelland and Stewart, Toronto, 1976, p.52, in Child Birth by Choice Trust, Abortion in Law, History and Religion, Toronto, Canada , 1995), p.3, (hereafter, the Trust).

${ }^{8}$ Ibid.

${ }^{9}$ J. T. Noonan, "An Almost Absolute Value in History," in The Morality of Abortion: Legal and Historical Perspectives, ed. (Cambridge, Mass.1970), p.3-4, in Judges, Supra Note 2, at 85.

${ }^{10}$ The Trust, Supra, Note 7 at. 3

${ }^{11}$ S. M. Krason and W. B. Hollberg, "The Law and History of Abortion: The Supreme Court Refuted," (cont.)
} 


\section{The Position of Different Religions on Abortion}

\section{1- Catholics}

The current debate on abortion is no doubt fueled by religious positions on the subject. Of all the religions, the position of the Catholic Church appears to have influenced the current position of many local laws, particularly in the western world. Some writers forward the view that, "The Bible ...is remarkably silent on the issue of [abortion] that some modern Christians regard it as akin to murder."12 According to Noonan, however, there is an express prohibition in Didache, or The Teachings of the Twelve Apostles (c.100 A.D.), which provides, "You shall not slay the child by abortion. You shall not kill what has been generated" but not in the other works such as that of Matthew, Luke or Galatia. ${ }^{13}$ Noonan cites second-century writings, including those of Clement of Alexandria and Tertullian, condemning abortion. Others however, have argued that Tertullian justified therapeutic abortions. ${ }^{14}$

At least starting from the time of Aristotle, "ensoulment"- a point of pregnancy from which the fetus can have a recognizable status, often regarded as occurring at forty days - became the border line to condemn or allow abortion. $^{15}$

[I]n the eleventh and twelfth centuries Roman Catholic opposition to contraception and to abortion became clearer... The writings of Ivo (bishop of Chartres from 1091 to 1116), Peter Lombard, and Gratian established that "both contraception and abortion were out of order and jeopardized a person's soul”. ${ }^{16}$

There were different positions in the church. "In 1588 Pope Sixtus V issued the bill Effraenatum, which equated abortion with homicide throughout pregnancy and without regard to maternal health". 17 Some, however, supported abortion for therapeutic reasons and rape. It appears that the Church had no uniform position on abortion till quite recently. Recent developments show that the Church's position is now much firm than it was in its earlier periods.

The decline of the ensoulment theory was accompanied by a hardening of the papal position on abortion. In 1869 Pius IX deleted references to "ensouled

\footnotetext{
${ }^{11}$ (cont.)...in Abortion, Medicine and the ${ }^{15}$ Supra, Note 2, Judges notes that a Council Law, ed .J. Douglas Butler and David L. of Eastern Bishops, the Council of Ancyra, Walbert, $3^{\text {rd ed }}$. (New York, 1986), 196-198, in 314 A.D. prohibited abortion without in Judges, Supra, Note 2 at 85

${ }^{12}$ Ibid at 87

${ }^{13}$ Noonan, p.9, in Judges, Supra Note 2 p.85. $\quad{ }^{16}$ Riddle, p.112, in Judges, Supra Note 2,

${ }^{14}$ C. C. Means, “ A Historians View," in at .87-88

Abortion in a Changing World, 1: 17- 18, in ${ }^{17}$ Noonan, 33-34 and Means, 18-19, 9 and 15, Judges at .87-88 respectively. In Judges Supra Note 2, at 89
} 
fetus" in the excommunication for abortion, a change interpreted as meaning that ensoulment occurred at conception. Several late-nineteenth-century papal pronouncements declared illicit many forms of therapeutic abortion. The new Code of Canon Law in 1917 specifically included 'mothers' among those to be excommunicated for procuring abortion. In 1930 Pius XI issued an encyclical condemning abortion for therapeutic, social, and eugenic grounds. And the Second Vatican Council declared in the early 1960s, "Life from its conception is to be guarded with the greatest care. Abortion and infanticide are horrible crimes.”18

The dramatic change in policy was dictated by the rising birth control movement that had resulted in the decline of the Catholic population, especially in France. Moreover, "in Italy, during the years 1848 to 1870, the papal states shrank from almost one-third of the country to what is now Vatican City. It has been argued that the Pope's restriction on abortion was motivated by a need to strengthen the Church's spiritual control over its followers in the face of this declining political power". ${ }^{19}$

This rigid position is not, however, shared by all followers. At least in Canada, Catholics for a Free Choice, which is a pro-choice group, believe that it is an individual woman's right to make decisions regarding abortion and contraception in accordance with her conscience. Moreover, according to a poll conducted in Canada, $77 \%$ of Catholic Canadians believe that abortion should be permitted in certain circumstances, and 36\% think it should be permitted whenever a woman decides she wants one. ${ }^{20}$ Although the Catholic Church appears to be the staunchest opponent of abortion, other religions also share this position to a certain extent. The positions of some churches are discussed here below: ${ }^{21}$

\section{2- Position of various churches: Sample overview}

There seems to be no unanimity on the subject, within the Anglican Church. This is because, the $29^{\text {th }}$ Synod in 1980 rejected abortion for reason of convenience or economic or social hardship and a 1983 report from a sub group of the Church's Task Force on Human Life held that in circumstances such as a real economic hardship, abortion may be a moral choice which should

\footnotetext{
${ }^{18}$ Noonan, p.39-45, in Judges, Supra, Note 2

Trust, cited above, which mainly focuses on at 89

${ }^{19}$ W. W. Watters, pp.92-93, in the Trust, sources obtained from religious representatives in Canada. Though it is not fully warSupra Note 7 at 4.

${ }^{20}$ Ibid at 40 .

${ }^{21}$ Note: The positions of the different religious groups discussed here are taken from the publication of Childbirth by Choice ranted, there is every reason to assume that these positions are equally shared by religious representatives in other parts of the world too, albeit, with some minor differences.
} 
not be denied. The Task Force stated that the fetal right to life is a diminished right if ...it stands in the way of a woman's health or sanity. In 1989, however, the Church took a position that abortion should be allowed only in cases where pregnancy endangers the woman's physical or mental health. It stated that abortion should never be used except for serious therapeutic reasons. ${ }^{22}$

The 1982 resolution of the Canadian Baptist Federation opposed abortion for any other reason other than to save the woman's life. ${ }^{23}$

The Evangelical Fellowship of Canada, representing approximately 25 conservative Christian denominations, adopted a strong anti-abortion stand in 1989, calling for a government policy that would make any abortion illegal unless performed to save the woman's life. ${ }^{24}$ This Church is divided on the issue of abortion, so much so that it is difficult to determine an official policy. What is officially known in this regard is that, the Church (in 1988) rejected abortion as a moral option except to prevent the death of a woman, and adopted an interim statement, which repudiates abortion on demand and upholds the sanctity of life in its 1989 convention. ${ }^{25}$

Jehovah Witnesses believe that in the eyes of the Creator, Jehovah God, it is a sin to make a life that one does not intend to care for, or to have an abortion. ${ }^{26}$ The Presbyterian Church holds that abortion should be lawful only if a pregnancy endangers the woman's life or is likely to impair her physical or mental health in a permanent or prolonged way. It has consistently opposed abortion on demand, and holds that there is no point after the moment of conception when the fetus does not qualify as human life. ${ }^{27}$

The $24^{\text {th }}$ General Council of the United Church stated (in January 1971) that "abortion is morally justifiable in certain medical, social and economic circumstances," and that "abortion should be a private matter between a woman and her doctor". It, therefore, called for the removal of abortion from the

\footnotetext{
${ }^{22}$ Motion of the $29^{\text {th }}$ General Synod of the Anglican Church of Canada, June, 1980 and, "Abortion O.K. in Some Cases, Anglican Church Says", The Toronto Star, May 14, 1988, in the Trust, Supra Note 7 at 39

${ }^{23}$ M. McAteer, Abortion; "Church Members as Divided as General Society Is”. The Toronto Star, Sept.2, 1989, in The Trust, p.39. It should be noted here that until 1984, the regional Baptist Convention of Ontario and Quebec accepted abortion when the pregnancy constituted a grave threat to the woman's life or health, when there was risk of a deformed child, and when the preg-

nancy was the result of rape or incest. In 1984, however, this group withdrew its position and brought it in line with the Federation's position. Id.

${ }^{24}$ Ibid. at 39.

${ }^{25}$ M. McAteer, in the Trust, Supra, Note 7 at 39-40.

26 "Life: A gift to be Cherished", Awake!, Watch Tower Bible and Tract Society of Canada, Georgetown, Ontario, May 22,1993, in the Trust, Supra, Note 7 at 40.

${ }^{27}$ M. McAteer, in the Trust, Supra, Note 7 at 40
} 
Criminal Code, except when performed by medically unqualified people and in places not approved for that purpose. ${ }^{28}$

\section{3- Buddhism, Hinduism and Humanists}

According to Buddhism, a fertilized egg is considered as a sentient being, and abortion is synonymous with killing. Nevertheless, there are position papers of the Buddhist Temples which emphatically state that the abortion decision is one, which the woman herself must make. ${ }^{29}$ The position of Hinduism is no different from that of Buddhism. Accordingly, it considers abortion as killing and thus inconsistent with the Hindu belief in non-violence. However, medically therapeutic abortions are tolerated. ${ }^{30}$

On the contrary, Humanists ${ }^{31}$ do not consider an embryo/fetus to be a person, but rather, to have the potential of becoming one. They see the abortion decision as a personal, moral choice for the woman and not ... the subject of criminal legislation. ${ }^{32}$

\section{4- Islam}

The majority of Muslim scholars permit abortion, although they differ on the stage of fetal development beyond which it becomes prohibited. Scholars agree that abortion at or after the ensoulment stage is prohibited except to save the woman's life. One group permits abortion up to 120 days after conception. Another prohibits it as early as eighty or even forty days after conception. In either case, many take the view that abortion does not abruptly become prohibited at a certain stage, but becomes increasingly disfavoured as the fetus develops, until it becomes finally prohibited. On the other hand, a minority of scholars hold a very strict view, which prohibits abortion from the very moment the semen attaches to the uterus, on the theory that it is already on its way to being ensouled. ${ }^{33}$

\footnotetext{
${ }^{28}$ United Church of Canada, "General Council Executive Updates United Church Policy Statement on Abortion", Press Statement Released Monday, November 27, 1989, in the Trust, at 40-41.

${ }^{29}$ Sugunasiri, S. "How Non-Christians Tackle Abortion”, The Toronto Star Magazine, Jan. 6, 1990, in the Trust at 41

${ }^{30} \mathrm{Id}$.

${ }^{31}$ It is to be noted that this outlook cannot be regarded as religion

${ }^{32}$ Supra, Note 28

${ }^{33}$ A.Y.al-Hibri, 'Family Planning and Islamic Jurisprudence', IN/FIRE Ethics, Newsletter

of the International Network of Feminists Interested in Reproductive Health', Vol.3, Issue 2, 1994, the Trust, p.42.

Note: Another scholar expressed the position of Islamic law as follows;

"[Despite some differences in opinion], according to the teachings of The Prophet Mohammed (sAas), the soul is placed in the fetus after 120 days...Thus, under Islamic law, the fetus is considered as a human being after the end of the fourth month.From this, it is clear that abortion after the month can only be allowed in Islamic law if... (cont.)
} 


\section{5 - Judaism, Sikhism and Unitarians}

According to Jewish Talmud compiled around 600 CE "an embryo is a limb of its mother". ${ }^{34}$ and for the first forty days after conception, the embryo is "simply water.",35

Abortion for therapeutic reasons, when the woman's life is clearly in danger, is mandatory in Judaism. Her life takes absolute precedence over the potential life of the fetus, which is not regarded as full life until late in the process of birth. Although there is no unified Jewish position on abortion; Rabbis in Reformed Judaism generally take a pro-choice stance toward a woman's decision for abortion. ${ }^{36}$

Sikhs emphatically state that the woman's right far outweighs the right of an embryo/fetus, which is not given the status of a human person. Accordingly, abortion is allowed up to a medically safe point. ${ }^{37}$ And, the Unitarians promote family planning and education for responsible sexuality, and support the right of all women to freely exercise their own conscience in the matter of abortion. $^{38}$

\section{Comparative overview of the legal regime in some countries}

Before we proceed to an overview of the legal regime in various countries, we may recall a widely read and highly popular question that was raised by Judith Jarvis Thompson nearly four decades ago:

You wake up in the morning and find yourself back to back in bed with an unconscious violinist. A famous unconscious violinist. He has been found to have a fatal kidney ailment, and the Society of Music Lovers has canvassed all the available medical records and found that you alone have the right blood type to help. They have therefore kidnapped you, and last night the violinist's circulatory system was plugged into yours, so that your kidneys can be used to extract poisons from his blood as well as your own. The director of the hospital now tells you, "Look, we're sorry the Society of Music Lovers did this to you - we would never have permitted it if we had known. But still, they did it, and the violinist now is plugged into you. To unplug you would be to kill him. But never mind, it's only nine months. By then he will have recovered from his ailment, and can safely be unplugged from you. ${ }^{39}$

\footnotetext{
${ }^{33}$ (cont.) ...it is the lesser of two evils, that is, ${ }^{36}$ The Trust., Supra, Note 7 at 42. Abortion”, Journal of Philosophy and Public Affairs, 1 (1971) at 47
} 
Judith Thompson then raised the question whether it would be morally incumbent to accede to this situation:

All persons have a right to life, and violinists are persons. Granted you have a right to decide what happens in and to your body, but a person's right to life outweighs your right to decide what happens in and to your body. So you cannot ever be unplugged from him. I imagine you would regard this as outrageous, which suggests that something is really wrong with that plausiblesounding argument I mentioned a moment ago." 40

\section{1 - USA, Canada and England}

Although restrictive abortion laws endured for a long time, many social and technological factors forced them to give way to more liberal laws. The advance in medical technology, women's enhanced awareness about their rights, and concerns about population militated against maintaining restrictive laws. It was under such a setting that American physicians opted for the relaxation of restrictive abortion laws, and movements towards asserting a woman's right to full control of her body enhanced the momentum. As a result, state laws allowed abortions for a variety of reasons, such as: best interest of the patient, sound clinical judgment, informed patient consent, avoiding harm to the woman's physical or mental health, avoiding birth of a fetus which will be born with serious mental or physical handicap, pregnancy resulting from rape, incest, and illicit intercourse with a minor girl. ${ }^{41}$

Moreover, a case decided by the Supreme Court of the United States in 1973 brought about a radical change in the abortion laws of the country. Roe $v$ Wade, is an important case because it established a federal constitutional right to abortion. In Roe $v$ Wade (1973)" ${ }^{\prime 2}$ the ruling of the US Supreme Court included the following:

During the first trimester of pregnancy, the state cannot bar any woman from obtaining an abortion from a licensed physician. During the second trimester, the state can regulate the abortion procedure only to protect the woman's health. In the third trimester, the state may regulate to protect fetal life, but not at the expense of the woman's life or health.

"The decision has endured a quarter century and remains essentially intact, despite many subsequent decisions." ${ }^{33}$ Roe's holding have dealt with issues such as interest of the state, husbands, parents, and others. ${ }^{44}$ It should, however, be noted that the decision on Roe $v$. Wade has not brought about a consensus between the pro-life and pro-choice lobbyists. Thus, the issue of abor-

\footnotetext{
${ }^{40}$ Ibid

${ }^{41}$ The Trust, Supra Note 7 at 108

${ }^{42}$ Roe v. Wade, 410 U.S. 113 (1973) 
tion is still a legally controversial issue in the United States. Different cases have been brought to the Supreme Court since 1973, among which Webster $v$ Reproductive Health Services (1989) and Planned Parenthood of Southern Pennsylvania $v$ Casey (1992), can be cited as examples. ${ }^{45}$

Canadian abortion laws have also passed through many changes through time. The 1869 law of Canada prohibited abortion and punished it with life imprisonment. In 1969, the criminal law was amended to legalize abortion when pregnancy poses a threat to the life or health of a woman. In 1988, in a case that involved a well known abortionist by the name of Dr. Henry Morgantaler, the Supreme Court struck down the abortion law as contrary to section 7 of the Charter of Rights and Freedoms (guaranteeing “ life, liberty and security” of the person) and the court reasoned out that, Section 251 [that part of the criminal law that allowed abortion for therapeutic reasons] clearly interferes with a woman's physical and bodily integrity. Forcing a woman, by threat of criminal sanction, to carry a foetus to term unless she meets certain criteria unrelated to her own priorities and aspirations, is a profound interference with a woman's body and thus an infringement of security of the per$\operatorname{son}^{46}$.

\footnotetext{
${ }^{45}$ Notes. The core decisions of the latter two land mark cases are the following:

-Webster v Reproductive Health Services (1989)

States may bar public employees and public hospitals from being used for abortions. States may also require doctors to conduct tests to try to determine whether a fetus can survive outside the womb.

- Planned Parenthood v Casey - 1992

Requirements of a mandatory 24 - hour delay before an abortion, lectures by doctors against abortion, consents from parents of minors, and reporting requirements did not constitute an " undue burden" on women seeking to end an unwanted pregnancy and such provisions are constitutional.

According to one observer, the position of the Supreme Court on abortion, has gone through four distinct evolutionary stages in the twenty years since Roe. In the first, dominated by Roe itself, the court explicitly recognized a constitutional right to abortion. In the second stage, the court elaborated some said expanded - the contours of abor-

tion rights, as challenges were brought to a variety of state laws regulating abortion. In the third stage the court reversed its expansive trend and began to authorize a great range of restrictive state regulation of abortion. And in the fourth and most recent stage, a narrow and fragile majority of the court announced its continuing commitment to Roe's “core holding” and the use of viability as a legal boundary but also substantially revised the constitutional test for previability abortion regulations. [Judges, p.109 $-110]$.

It is also interesting to note that the controversy over abortion is still an ongoing process in the U.S. The pressure to maintain the current position or over turn it or make it more restrictive is reflected in the positions of those political parties that held power at different times. The Republicans are prolife, while the Democrats are pro- choice. These parties have appointed judges who can advance their causes and repealed or amended legislation to suit their positions.

${ }^{46}$ The Trust, Supra Note 7, at 35-38.
} 
England substantially liberalized its abortion laws in 1967 by allowing the range of justifications for therapeutic abortion to include almost any aspect of the pregnant woman's circumstances, including the impact on existing children. ${ }^{47}$ It is also believed that the reduced influence of religions at this time enhanced a secular and pragmatic mindset regarding the issue of abortion.

\section{2 - France, Belgium, Portugal and Germany}

The French Napoleonic Code of 1810 and its successive formulations prohibit abortion in absolute terms. The criminal law made an exception to this sweeping prohibition in 1939 by allowing abortion performed under a state of necessity, i.e. to prevent an immediate and more serious harm, such as the death of the pregnant woman. In 1975, France enacted a public health legislation that allowed the performance of abortion during the first ten weeks of pregnancy (now 12 weeks) on a pregnant woman who found herself in a "situation of distress" because of the pregnancy. ${ }^{48}$ This law also allowed abortions to be carried out later in pregnancy if two physicians certified that the pregnancy posed serious danger to the woman's health or if there was a strong possibility that the child would suffer from a particularly severe illness recognized as incurable at the time of diagnosis. The law had also provided for a waiting period of one week before abortion and mandatory counseling provided by a person other than her physician. These obligations were left out in 2001.

Belgium's Penal Code, like that of France, was largely based on the Napoleonic Code of 1810 as reformulated in 1867. The law, therefore, used to prohibit abortion. Belgium, however, amended its law in 1990 and allowed

${ }^{47}$ The Abortion Act of 1967 reads in part as follows:

Sec.1- Medical Termination of Pregnancy

1. Subject to the provisions of this Section, a person shall not be guilty of an offence under the law relating to abortion when a pregnancy is terminated by a registered medical practitioner if two registered medical practitioners are of the opinion, formed in good faith...

a) that the pregnancy has not exceeded its twenty- fourth week and that the continuance of the pregnancy would involve risk, greater than if the pregnancy were terminated, of injury to the physical or mental health of the pregnant woman or any existing children of her family; or b) that the termination is necessary to prevent grave permanent injury to the physical or mental health of the pregnant woman; or

c) that the continuance of the pregnancy would involve risk to the life of the pregnant woman, greater than if the pregnancy were terminated ; or

d) that there is a substantial risk that if the child were born it would suffer from such physical or mental abnormalities as to be seriously handicapped.

${ }^{48}$ Reed Boland and Kibrom Teklehaimanot, Abortion Law and Practice in Africa, Eudora/attach/Africa/paper6.5.02doc.pp5-10 (2002) (hereinafter B\&T.Haimanot). 
abortion for a variety of reasons. The changes made in the 1990 legislation are very similar to the 1975 law of France. ${ }^{49}$

Portugal's Penal Code provisions had prohibited abortion in an absolute manner until they were amended in 1984 after which they allowed abortion for a variety of reasons including termination of pregnancy when there are significant indications that the pregnancy resulted from rape. However, such permissive abortion must be performed during the first 12 weeks of pregnancy. ${ }^{50}$

In pre-World War II Germany and in particular under the Weimar Republic, public awareness towards birth control was steadily growing until the early 1930s. In 1933, birth control centers were closed and advertising of contraceptives were prohibited. While the Nazi Party was in power in Germany, abortion was strictly forbidden, as "Aryan" women were to reproduce to increase the "master race". Abortion was declared an act against the state and the death penalty was introduced in 1943. Despite this restrictive law and its severe punishment, Jewish women were forced to have abortions; both abortion and sterilization were used by the state against groups that were considered racially undesirable. ${ }^{51}$

East Germany enacted a law in 1972 that allowed abortion for a variety of reasons; West Germany also enacted a similar law in 1976. After reunification, a 1992 law permitted first trimester abortions on request after mandatory counseling and three-day waiting period. A follow-up law allowing abortions during the first twelve weeks of pregnancy, provided that the woman undergoes counseling by a doctor, was narrowly approved by Germany's parliament in $1995 .^{52}$

There is an interesting issue that needs to be noted in the European context regarding a direct conflict between abortion laws of an European state and EU Laws. Society for the Protection of the Unborn Children (Ireland) Ltd. V. Grogan 53 "was the first case in which a member state, Ireland, referred a case to ECJ regarding the direct conflict between national and community abortion laws."54 The details of the outcome of the case fall beyond the scope of this article.

\footnotetext{
${ }^{49}$ Id.

${ }^{50}$ Id.

${ }^{51}$ The Trust, Supra, Note 7 at 9-10.

${ }^{52}$ Ibid at $10-11$

${ }^{53}$ Society for the Protection of the Unborn
}

Children (Ireland) Ltd. v. Grogan and others, [1997] 317/92

${ }^{54}$ A. Czerwinski, "Sex, Politics and Religion: The Clash Between Poland and European Union over Abortion," 32 Denv. J. Int'l law \& Policy 662 (2003-2004) at 662 


\section{3 - Asia and Oceania}

The abortion laws of Asia and Oceania exhibit major differences that are prompted by dominant religious beliefs, colonial legacy or concern over population growth. In Bangladesh, the law prohibits abortion under many circumstances. ${ }^{55}$ Since 1957, the Chinese law allows abortion on request. In 1979, China has adopted a "one child" policy in urban areas, while rural families may have up to two children. This policy has been criticized for forcing women to abort against their will. ${ }^{56}$

Abortion is legal in India since 1971, and the burgeoning population growth was a factor for legalizing the act. ${ }^{57}$ In Indonesia, abortion was technically illegal. However, a judicial interpretation rendered in 1970, permitted medical professionals to offer the procedure so long as they were discreet and careful. The 1992 Health Law of the country provided among others, that "certain medical procedure" could be performed to save the life of the pregnant woman. According to the views of some critics, the new law made the situation more confusing and the word "abortion” was avoided by legislatures in order to avoid political risk. ${ }^{58}$

In Malaysia, a former restrictive law is recently repealed by a new one modeled on the English statute. The new law allows abortion if continuing a pregnancy involves more risk to a woman's physical or mental health than terminating it. ${ }^{59}$ Pakistan had a restrictive law that was imposed by the British during colonial rule. In 1991, however, the country replaced this law with more liberal criminal legislation designed to conform to the principles of Islamic law. According to the latter law, abortion in the earlier stage of pregnancy is no longer a crime, if it is carried out to provide "necessary treatment". ${ }^{60}$

In Australia, the laws governing abortion fall within the legislative responsibility of the eight individual states and territories. All criminal abortion codes were originally based on English law of the mid- $19^{\text {th }}$ century and South Australia is the only state where an Act of Parliament has formally legalized abortion, in 1969. In all the other states, though abortion remains a criminal offence, common law precedents have allowed practitioners to carry out legal abortions where they consider it is necessary for the health of the pregnant woman. ${ }^{61}$ A law enacted in 1977, in New Zealand, allowed abortion under very particular conditions, such as, rape, extreme stress for the woman, or

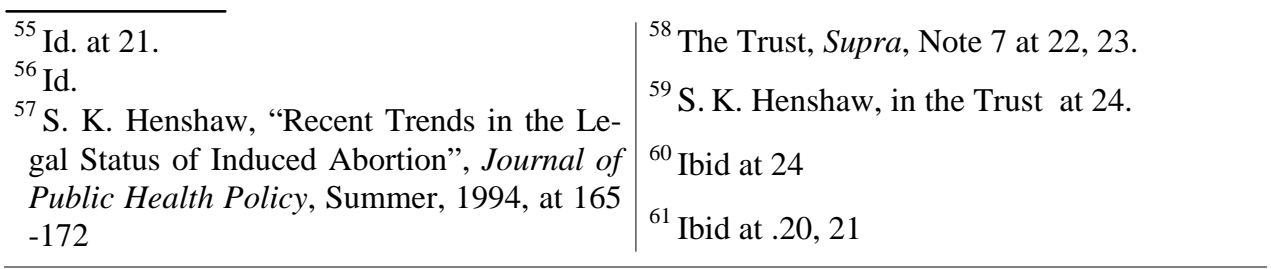


danger to the woman's life. These restrictions were, however, somewhat relaxed in $1978 .^{62}$

Japan enacted a law in 1948 that allowed abortion in cases of rape, genetic foetal defects, and damage to the woman's health. Economic considerations were added in 1949. In 1976, the law limited the period of permissible abortion from 28 weeks to 24 weeks of pregnancy; and in 1991, the period during which abortion was allowed was cut to 22 weeks of gestation. ${ }^{63}$ In Philippines, which is Asia's only Catholic nation, abortion is illegal under its 1986 Constitution; and the right to life is recognized "from the moment of conception". ${ }^{64}$ Abortion is legal on request, in Vietnam. The government's strict 1988 "two child policy" imposes fines on above quota births. ${ }^{65}$

\section{4 - The Middle East}

In Iran, abortion is illegal, except to save the life or physical or mental health of a woman, or in cases of fetal impairment. The government, however, outlawed abortion in 1979, i.e. after the Islamic revolution. After 1988, i.e. the end of Iran's war with Iraq, population explosion has been increasingly seen as a major obstacle to economic reconstruction and as a result, the government has reversed its pro-natalist policies thereby officially promoting family planning. ${ }^{66}$

Since 1983, Turkey allows abortion on request up to the end of the $10^{\text {th }}$ week of pregnancy. Married women, however, need the consent of their husbands ${ }^{67}$. In Jordan, as in the rest of the Arab countries, abortion is illegal (with a few medical exceptions) under the legacy of the French and English laws, which have undergone little serious revision. ${ }^{68}$

Israel's law was liberalized in 1977 to allow abortion to avert "grave harm to the woman or her children owing to difficult family or social circumstances". However, in response to Ultra-Orthodox pressure, the law was amended in 1979, and the social indication was rescinded. Under the current law, abortion is permitted when performed under any one of the following conditions: The woman is under 17 (the legal age of marriage) or over 40; the pregnancy results from a criminal act (rape or incest) or from an-out-of wedlock rela-

\footnotetext{
${ }^{62}$ Ibid at 24

63 “Japan's proposal on Abortion Law Draw Fire”, The Toronto Star, April 30, 1990, in the Trust, p.23

${ }^{64}$ J. L. Jacobson, "The Global Politics of Abortion”, World watch paper 97, July1990 at 20

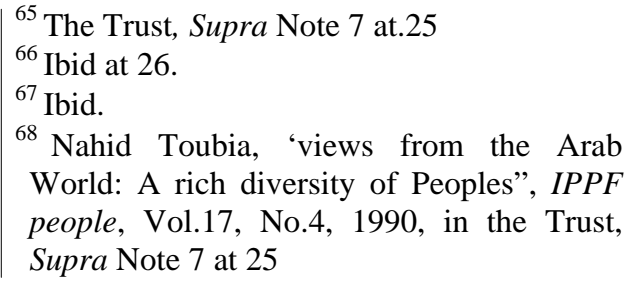
World: A rich diversity of Peoples", IPPF people, Vol.17, No.4, 1990, in the Trust, Supra Note 7 at 25 
tionship; there is suspected physical or mental malformation of the fetus; and continuation of the pregnancy may endanger the woman's health or life. ${ }^{69}$

\section{5- Anglophone African countries: Sample Overview ${ }^{70}$}

England was the first colonial power to liberalize its abortion law in 1967, and former colonies of England seem to have followed suit. The laws of Zambia in 1972, Zimbabwe in 1977, Seychelles in1981, Ghana in 1985, and Botswana are based on the 1967 Act of England. In Zambia, abortion can be carried out on broad indications, such as threat to life, physical or mental health and socio-economic indications. The law of Seychelles permits abortions to be performed on the ground of pregnancy resulting from rape, incest, or defilement, and in cases of serious mental disorder.

The laws of Ghana and Botswana allow abortions to be carried out: when the pregnancy is the result of rape, defilement, or incest; when the continuation of the pregnancy would involve risk to the life of the pregnant woman or injury to her physical or mental health; or, when there is substantial risk that if the child were born, it may suffer from, or later develop, a serious physical abnormality or disease. "Before 1975, the South African common law prohibited abortion under any circumstances except when the life of the mother was endangered."71 Nevertheless, "illegal abortion was a roaring trade for the medical profession by the late sixties."72 Decades later, we now see that South Africa has gone a long way and has one of the most liberal laws in the world regarding freedom to abortion.

In Egypt, whose Penal Code is based partly on Ottoman law, it is reported that abortions are allowed in case of threat to health and fetal defect. The Penal Code of Sudan that was enacted in the 1980s based on the principles of the Quoran, allows abortion on the following grounds: to protect the life of the mother; if the pregnancy was the result of rape and is of less than 90 days duration; and if it is proven that the fetus is dead in the mother's womb.

\section{6 - French Speaking African Countries: Sample Overview}

Abortion reform in countries formerly under French control has been less comprehensive and most of them have failed to follow the reform in France

\footnotetext{
${ }^{69}$ E. F.Sabatelo, "Estimates of demand for ${ }^{71}$ D. Hansson \& D. E.H. Russel, "Made to abortion Among Soviet Immigrants in Is- Fail: The Mythical Option of Legal Abortion rael”, Studies in family planning, Vol.23, for Survivors of Rape and Incest," South No4, July/August 1992 at .270-1 African Journal on Human Rights (9 S. Afr. ${ }^{70}$ E. B \& T Haimanot, Supra, Note 48, at 11 Most of the following legal positions of African Countries are based on this material. ${ }^{72}$ Ibid.
} 
as a model - unlike the situation in former English colonies. Tunisia was the first country to liberalize its law in 1965, before France in fact. Under this law, abortions are allowed on request during the first twelve weeks of pregnancy and thereafter, any time in pregnancy if there is a threat to the pregnant woman or if the child to be born will suffer from a serious disease or disability.

The Penal Code of Morocco (amended in 1967) allows abortion to be performed at any point during pregnancy to preserve the health of the pregnant woman. Prior to 1976, Algeria had a law that prohibited abortion, except to save the life of the pregnant woman. In 1976, however, a new health law authorized abortions to be carried out to preserve the seriously threatened health of the pregnant woman. Another new law enacted in 1985 clarified that the threat to health includes a threat to psychological as well as physical health. Cameroon's Penal Code permits an abortion to be carried out to save the pregnant woman from a serious threat to her health and in cases of rape, after the prosecutor makes a statement of the materiality of the facts. Togo and Benin removed all provisions relating to abortion from their Penal Codes, in 1980. Djibouti's 1995 Penal Code allows a pregnancy to be terminated by a physician for therapeutic reasons.

Comoros amended its Penal Code in 1982 to allow abortions to be carried out for serious medical reasons. Burkina Faso enacted a Penal Code in 1997 and under this law; abortion can be carried out at any point during pregnancy if the pregnancy places the health of the woman in danger or that there is a strong probability that the child to be born would suffer from a particularly severe illness recognized as incurable at the time of diagnosis. Moreover, the Code allows a termination of pregnancy, when the pregnancy is a result of rape or incest, the materiality of which has been established by the Public Prosecutor.

The Penal Codes of Chad, The Central African Republic, Congo, Madagascar, Mali, Mauritania, and Senegal prohibit the performance of all abortions. Côte d'Ivoire, Guinea, Chad, and Madagascar allow abortion only when it is necessary to save the life of the pregnant woman.

\section{7 - The spectrum in Africa's march towards liberal laws on abortion}

The following are six commonly cited instances ${ }^{73}$ in which abortion is permitted:

73 http://www.un.org/esa/population/publications/abortion/doc/Notes.doc Accessed: January 13, 2008 
a) "Intervention to save the life of the woman (life grounds);

b) Preservation of the physical health of the woman (narrow health grounds);

c) Preservation of the mental health of the woman (broad health grounds);

d) Termination of pregnancy resulting from rape or incest (juridical grounds);

e) Suspicion of foetal impairment (foetal defect);

f) Termination of pregnancy for economic or social reasons (social grounds).”

In addition to these six levels in the spectrum of freedom to abortion, liberal abortion policies allow a seventh category, i.e. abortion upon request (subject to some procedural regulations). It is interesting to note that out of fifty-three African countries, twenty-two fall within Level I in the freedom to abortion (i.e. allow abortion only to save the life of the pregnant woman); and only three African countries (namely Cape Verde, South Africa and Tunisia) have attained Level VII in the degree of freedom to abortion by allowing abortion upon request, of course with some regulatory framework which guards against spontaneous whims. ${ }^{74}$

Seven African countries (that allow abortion on grounds "a or b" stated above) belong to the Level $\mathrm{II}^{75}$, and 13 countries fall within Level $\mathrm{III}^{76}$ (because they allow abortion on grounds “a or b or c"). The majority of African legal regimes on abortion thus fall within Levels I to III in the spectrum of freedom to abortion. It is indeed surprising that most abortion laws in Africa haven't yet elevated their abortion laws to Level IV which allows termination of pregnancy resulting from juridical grounds of rape or incest.

\section{8- The impact of restrictive abortion laws on maternal and infant mortality}

Poverty, extreme youth, unpreparedness for motherhood, abuse, abandonment by a partner ${ }^{77}$ are some of the factors the lead to abortion due to unwanted pregnancy. Current social realities clearly show that there are numerous reasons which create the will and determination in many women to ter-

\footnotetext{
${ }^{74}$ http://www.un.org/esa/population/ publications/abortion/profiles.htm Accessed: January 13, 2008

Revised 2004 Criminal Code) that has been used as the basis for Ethiopia's classification into Level III.

${ }^{75}$ Ibid

${ }^{76}$ Ibid - It is to be noted that Ethiopia has not yet updated the data in the Profiles because it is the 1957 Penal Code (rather than the

${ }^{77}$ B. Radford \& G. Shaw, "Beyond Roe and Abstract Rights”, Louis U. Pub. L. Rev. 209 (1993-1994) at 209
} 
minate pregnancy. World Health Organization's (WHO) database and periodical studies ${ }^{78}$ show that abortion is widely practiced throughout the world legally as well as illegally. According to reports, nearly 20 million unsafe abortions took place in 2003, 98\% of them in developing countries with restrictive abortion laws. In another study conducted in 1991, an estimated 26 to 31 million legal abortions and 10 to 22 million clandestine abortions were performed worldwide in 1987. Legal abortion rates ranged from a high of at least 112 abortions per 1,000 women of reproductive age in the Soviet Union to a low of 5 per 1,000 in the Netherlands. Other statistics indicate that China performed 10,394,500 abortions in 1987 alone. [In the same year], 6,818,000 abortions were performed in the Soviet Union. ...In 1975, 2,250,000 abortions were performed in Japan and in 1982, 11million abortions were performed in the Soviet Union. ${ }^{79}$

Illegal abortion is shown to be the major cause of maternal mortality in many countries and a cause for infanticide, abandonment of newborns, selling of unwanted children and placement of so many children in orphanages. The data also reveal that Latin America and Africa are the worst affected regions in this regard. Latin America and the Caribbean had the highest incidence of induced abortion in the developing world, with between 2.7 and 7.4 million performed each year. Moreover, complications arising from these procedures are the principal causes of death among women of reproductive age. Approximately 800,000 Latin American women are admitted to hospitals every year for post-abortion complications.

Abortion is a major public health problem for most of Africa, where most of the abortions carried out are illegal and hence unsafe. For example, "the restrictive statutory formula has driven many pregnant women and girls to nonphysician providers in a bid to avoid reluctant parenthood by accessing secretly illegal and septic abortions" ${ }^{\$ 0}$ which are unhygienic and unsafe.

Almost 5 million unsafe abortions are performed each year, approximately 30 unsafe abortions per 1,000 women of reproductive age. Of these 5 million abortions, a disproportionately high number of the world total result in death: 34.000 a year, $40 \%$ of the world total, at a rate of 100 per 1,000 live births.

\footnotetext{
${ }^{78}$ http://www.who.int/reproductive-health/ ${ }^{79}$ S. K. Henshaw, Induced Abortion: A World nual Estimates of Incidence and Mortality, Unsafe Abortions, United Nations Regions, 1995-2000 and Report for 2003, $5^{\text {th }}$ Edition, Geneva,2007, last visited on November 8,2007.

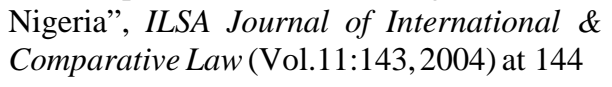
Nigeria”, ILSA Journal of International \& Comparative Law (Vol.11:143, 2004) at 144

${ }^{80}$ V.N. Opara, "Re-characterizing abortion in
} 
Maternal mortality rates are 880 deaths per 100,000 live births, and 12-13\% of all maternal deaths are the result of unsafe abortions. The risk of death from unsafe abortions is one in 150 procedures, and this is by far the highest in the world. ${ }^{81}$

Despite legal reforms and improved access to health services in many countries, latest figures show that the situation is not encouraging. The incidence of unsafe abortion is still very high in Africa and South America, compared to other regions. The estimates for the year 2003 show that only about $40 \%$ of women of reproductive age live in countries where abortion is available on request and there is no evidence of unsafe abortion. On the other hand, unsafe abortion rates are close to 30 per 1000 women of reproductive age in both Africa and Latin America. ${ }^{82}$ Thus, in these regions, unsafe abortion is still a major cause of maternal mortality and responsible for, inter alia, the consumption of a significant share of resources, including hospital beds, blood supply, medication, and often operating theatres, anesthesia and medical specialists.

Based on analysis of data gathered on the correlation between restrictive abortion laws and maternal and infant mortality rates, Chad M. Gerson noted that lesser access to abortion is correlated with higher rate of maternal and infant mortality:

"Access to abortion in inversely correlated with both maternal and infant mortality. These correlations are suggestive of a palpable cause and effect relationship between access to abortion and maternal and infant mortalities., ${ }^{, 3}$

Recent figures show that Burundi, Chad, Ethiopia, Guinea, Mozambique, Rwanda, Sierra Leone and Somalia have the highest mother mortality rates of 1,300 or above per one hundred thousand live births. ${ }^{84}$ It is to be noted that three countries with restrictive abortion policies (Egypt, Libya and Mauritius) ${ }^{85}$ have managed to have very low maternal mortality rates owing to another significant variable, i.e. very high per capita income compared to most countries in Africa.

With regard to infant mortality, Angola, Guinea-Bissau, Liberia, Niger, Sierra Leone and Somalia have the highest rates which range from 130 to 165 per one thousand deliveries. ${ }^{86}$ Ethiopia's infant mortality rate, i.e. 114 per one thousand deliveries is also considerably high.

\footnotetext{
${ }^{81}$ See Judges or Trust for general world data and R \& T. Haimanot, for African data.

${ }^{82}$ WHO, above, 2007.

(Fall 2006), 373, page 380

${ }^{84}$ Id at 377.

${ }^{83}$ C. M. Gerson, "Toward an International Standard of Abortion Rights: Empirical Data From Africa." 18 Pace Int'L Law Review.

${ }^{85}$ Id. at. $380-81$.

${ }^{86}$ UNICEF: The State of the World's Children 2004: Basic Indicators (cited in Gerson, Note 72 at 377)
} 


\section{Ethiopia's Abortion Laws up to 2004}

Christianity, Judaism, Islam as well as other religions were practiced in Ethiopia before the $15^{\text {th }}$ Century. Moreover, as a country of multiple nations, nationalities and peoples, there are a number of customary laws that can serve as bases of laws and may have bearing on abortion. However, due to dearth of materials pertaining to the subject at hand, it cannot be ascertained with certainty that abortion was a proscribed act before this period.

\section{1- The Feteha Negest}

The Feteha Negest was not penal law in the strict sense, and it embodied provisions of penal law, family law, and successions. Most of its contents dealt with religious affairs. Moreover, it was not binding on non-Christians. The part of the Feteha Negest which dealt with abortion provided the following:

"If a woman conceives and wants to abort the unborn child in her womb, she shall be beaten and exiled."

Chapter XLVIII, Corporal and Spiritual Punishment for Fornication; VII- 72

"If a man makes a woman abort with poison and lies with her, he must remain outside the church for the rest of his life or in danger (if he is not on the verge of death) must he be deemed worthy of receiving the Holy mysteries, because he has committed the three greatest sins: fornication, homicide, and sorcery. As for women who commit carnal sins and kill their children afterwards and hide their death, first it was provided, with reference to them that they be expelled (from the community) until the day of their death, but because of the great mercy of God towards us the penalty shall be for ten years, as it has been commanded."

Chapter XLVII, Homicide and its Corporal and Spiritual Punishment as Contained in its Canons) [End of Part XII] - on Spiritual Punishment.

\section{2- The 1930 Penal Code.}

The position of the 1930 Penal Code on abortion was absolute because it allowed no exceptions. It should also be noted that though the law had acknowledged criminal defenses, such as, legitimate defense, superior order, infancy, etc., the defense of necessity was not recognized under this law. ${ }^{87}$ Six provisions of the Code dealt with the crime of abortion. According to Article 381, abortion or consent to abortion was punishable by imprisonment from one up to three years and/or a fine ranging from 10 up to 50 Birr. And, performing an abortion upon the consent of the woman was punishable by imprisonment (Article 382) from one month up to one year and a fine ranging from 50 up to 200 Birr. The punishment for a middle man who brought together the abortionist and the pregnant woman was the same punishment

${ }^{87}$ See Articles, $145-151$ of the Code. 
provided for physicians and mid wives plus one -third, when the abortion is consummated (Article 383).

Abortion accompanied by violence or other means was made punishable by imprisonment from 15 up to 20 years (Article 384) if the offender was aware of the pregnancy of the woman. And, according to Article 385, a person who carried out abortion was liable to imprisonment from three up to seven years and/or a fine ranging from 3,000 up to 7,000 Birr if the abortion was consummated.

\section{3. - The 1957 Penal Code.}

The Penal Code of 1957 contained nine provisions that specifically dealt with abortion. Section 2 of Book V, Chapter I is entitled "Offences Against Life Unborn: Abortion". Article 528 dealt with general principles that governed the crime and its punishments, as well as the exceptional grounds under which abortions may be performed, legally. It also stipulated that the requisite criminal mentality for liability is intention, but not negligence or imprudence. According to Article 529, self-abortion was punishable with simple imprisonment from three months to five years, and procuring means or aiding are punishable with simple imprisonment from one to five years. And, abortion procured by another (upon consent) entailed rigorous imprisonment not exceeding five years (Article 530). Where the woman was incapable of giving her consent, or where such consent was extorted by threats, coercion, or deceit, or where she was incapable of realizing the significance of her actions, or where the intervention was effected against her will, the punishment was rigorous imprisonment from three to ten years.

Where abortion was performed for gain, or where the offender habitually made it a profession, he was liable to an additional penalty of fine (Art.531). However, abortion made on account of an exceptionally grave state of physical or mental distress (Article 533), especially following rape or incest, or because of extreme poverty, entitled the offender to free mitigation of sentences. The only exception where abortion was not punishable was when it was made to save the pregnant woman from grave and permanent danger to life or health which were impossible to avert in any other way, and in the case of grave and imminent danger which can be averted only by an immediate intervention (Arts. 534 \& 536). It can be noted, that the 1957 Penal Code made a significant departure from the Feteha Negest and the 1930 Penal Code in recognizing such exceptions. This was consistent with liberal laws of Europe, in the late 1950s. 
Analysis of Articles 533 and 534 of the 1957 Penal Code in light of the Seven Levels of Freedom to Abortion (discussed earlier) under Section 3.7 indicates the following:

\section{Table I - Grounds on which abortion is permitted ${ }^{88}$ \\ - To save the life of the woman............................... Yes \\ • To preserve physical health................................ Yes \\ • To preserve mental health................................. Yes* \\ • Rape or incest......................................... No \\ • Foetal impairment......................................... No \\ • Economic or social reasons................................. No \\ • Available on request................................. No \\ *The Penal Code does not specify whether a threat to health includes both physical and mental health.}

Article 533, in principle, considers abortion as an offence, but entitles the accused person to free mitigation where "the pregnancy has been terminated on account of exceptionally grave state of physical or mental distress, especially following rape, or incest, or because of extreme poverty." Grave state of physical health or mental distress, if caused by rape or incest or as a result of extreme poverty, can entitle the accused to free mitigation, while the latter factors (i.e. rape, incest or extreme poverty) do not on their own suffice as grounds of free mitigation unless they in addition bring about grave state of physical health or mental distress.

Article 534 goes beyond free mitigation and declares abortion unpunishable where "it is done to save the pregnant woman from grave and permanent danger to life or health which is impossible to avert in any other way." The term "health" in Article 534 does not seem to include "mental health" and as shown in the Table above, the 1957 Penal Code falls within Level II in the range of freedom to abortion, with some ambiguity whether the term "health" includes mental health in which case, the Penal Code could have been elevated to Level III.

\footnotetext{
${ }^{88}$ http://www.un.org/esa/population/publications/abortion/profiles.htm Accessed on January 13, 2008
} 


\section{4 - The practice of abortion until the advent of the 2004 Criminal Code}

There are ample data that prove the magnitude of abortion and their consequences despite the punishments stated under various provisions of the 1957 Penal Code. Two prominent groups, namely, The Ethiopian Society of Obstetricians and Gynaecologists (ESOG) and IPAS (International Products And Services) have done extensive researches in the area and published their findings at different times.

\section{ESOG's Survey $^{89}$}

The surveys were conducted between 1981 and 1999 in Addis Ababa, Gonder, Jimma, Yirga Alem, North Western Ethiopia and Gambella. Representative samples revealed that between August to February 1990 in five hospitals in Addis Ababa;

a) A total of 2275 patients were interviewed and 1296 (56.7\%) admitted to have had induced abortions, while $43.3 \%$ stated they had spontaneous abortions.

b) There were a total of 7158 deliveries and the abortion frequency was 317.8 / 1000 deliveries and the incidence of induced abortion was 200/ 1000 deliveries.

c) Of the induced abortion cases, $46.6 \%$ interfered with the pregnancy at the gestational age of $13-20$ weeks. In $97.5 \%$ of the induced abortion cases, the pregnancy was not planned. $83.6 \%$ did not want a child now, and in $43.1 \%$ of the cases, the partner was not in favour of having a child now.

d) A total of 1712 units of blood were used and of these 404 units were used for all abortions cases. Cases of induced abortion consumed 289 (73.3\%) of the 404 units of blood. The induced abortion cases received more blood and plasma expanders than the spontaneous abortion cases. The mean length of hospital stay was higher among cases of induced abortion, compared to cases of spontaneous abortion (2.69 days vs. 1.69 days, respectively).

e) There were a total of 69 maternal deaths and abortion related deaths contributed $52.2 \%$ of all maternal deaths. Of these, 35 (97.2\%) were induced abortion cases.

In another survey conducted in Jimma between October 25 and November 25, 1999 the study conducted on 205 women of reproductive age group, found that:

a) $51 \%$ the unwanted pregnancies were terminated;

\footnotetext{
${ }^{89}$ See ESOG, A Database on Abortion, Literature Review, October, 2000, ESOG: Report on Survey of Unsafe Abortion in Health Facilities in Ethiopia, May, 2002
} 
b) $93.3 \%$ of women with induced abortions were aged less than 30 years;

c) $57 \%$ were single and $64 \%$ had high formal education;

d) The most common reasons for failure to prevent unwanted pregnancy were improper use of contraception (19\%), unintended intercourse (18\%) and modern contraception failure (17.2\%).

A study conducted between July 1 and December 31, 2000 in 15 hospitals and eleven administrative regions ${ }^{90}$ the study found out that:

a) A total of 1075 cases were studied and women in the age group of $20-29$ accounted for $58.3 \%$ of all cases; $53 \%$ were house wives; $63 \%$ were married while the rest were single; students accounted for 14.6\%; and 47.9, 20.4,17.8, and 6.2\% of all patients were Orthodox Christians, Muslims, Protestants and Catholic Christians, respectively.

b) Non use of contraceptive method was responsible for $78 \%$ of pregnancies and $19 \%$ of the women reported that unwanted pregnancy occurred due to contraceptive failure and rape accounted for only $3 \%$ of all pregnancies that ended in unsafe abortions.

c) A total of 13 deaths were reported and this is high even by African standards.

d) The total cost of treatment of incomplete abortion was Birr 332, 259.90 and the average cost for such treatment in government health facilities was estimated at Birr 309.38, thus abortion costs almost ten fold than normal delivery.

e) 250 cases of induced abortions and 619 of spontaneous abortions were from urban areas, while 25 cases of the former and 179 cases of the latter were from the rural areas.

IPAS's survey $^{91}$

The study was conducted between July and September 2000 and it covered Oromia, Addis Ababa and Amhara. The following are its major findings:

a) Of those facilities that provide uterine evacuation services, only $26 \%$ were staffed by obstetricians/ gynecologists. Non specialists and mid level providers were much more common, staffing nearly $70 \%$ of these facilities.

\footnotetext{
${ }^{90}$ All regions of Ethiopia except Benishangul and Harrari are included in the study. Moreover, the study covered $98 \%$ of the total population.

${ }^{91}$ IPAS, Responding to Unsafe Abortion in Ethiopia: A Facility Based Assessment of Post Abortion Care Services in Public Health Sector Facilities in Ethiopia ${ }_{2}$ June,2002.

Notes:

- IPAS is an NGO that works to improve women's lives through a focus on reproductive health. Authors of this report are: Gebre Selassie, H. and T.Fetters.

- The details of the surveys are very extensive and comprehensive. Thus, the following are general summaries only.
} 
b) Of the 1,295 women suffering from abortion related complications and managed in the sample centers, in three months period, 94\% were treated using sharp curettage - the unacceptable method - and only 5\% were treated using MVA (Manual Vacuum Aspiration) and 1\% were referred to higher level facilities.79\% of patients that had MVA and 71\% of those who had curettage were given no analgesics and the reasons given were absence or shortage of these substances.

Based on the above findings, the Ministry of Health concluded that "abortion is found to be the leading cause of hospital admission for women in 1994/95 and also the second most frequent cause of death next to tuberculosis in the same year". ${ }^{92}$

\section{The Revised Criminal Code of $\mathbf{2 0 0 4}$}

The Revised Criminal Code has maintained most of the provisions of the former Ethiopian Penal Code, including the order of articles. This law has, however, introduced the following major changes:

a) The former law exempts those who committed abortion negligently under Art. 528(1), Paragraph 3. This defense has been omitted from the new law and the probable reason is that under (Article 59/2) of both Codes, negligent acts are made punishable only when the law expressly so provides and it will be redundant to show the same in the Special Part.

b) The 2004 Criminal has repealed Articles 802 and 528/2 of the 1957 Penal Code. Under the 1957 Penal Code advertising for abortive means was punishable.

c) The punishments provided under Art. 529 of the former law for a woman who procures her own abortion and against those who procured for her the means of or aid her in the act are reduced from 3 months up to five years simple imprisonment and 1 to 5 years simple imprisonment respectively, to simple imprisonment, Art. 546(1) \& (2).

d) The punishment provided for those who perform abortions or assist in the act contrary to the law under Art.530 of the former law is reduced from rigorous imprisonment not exceeding five years to simple imprisonment, under Art. 547(1).

e) Consenting to abortion contrary to the law was not an illegal act under the former law. Under the Revised law, however, it is an offence punishable with simple imprisonment, Art. 547(3).

f) The former law did not provide for a special punishment for those persons who perform abortions without having proper medical profession.

${ }^{92}$ Ministry of Health of Ethiopia, Health and Health Related Indicators, Jan. 1998, p.32. quoted in ESOG,(2002) Note: The statistics kept by the Federal Police Commission and the Ministry of Justice do not show significant numbers of legal cases pertaining to abortion. 
The Revised law has, however, made this act punishable by simple imprisonment for not less than one year, and fine, Art. 548(1) (b).

g) The major departure from the former law is reflected under Art. 551 of the Revised law which deals with "Cases where terminating pregnancy is not punishable". According to this provision, termination of pregnancy resulting from rape or incest, which was a ground of mitigation under the former law (if it entails exceptionally grave state of physical or mental distress), are no more punishable (Art. 551/1/a), and mere statement of the woman is adequate to prove that the pregnancy resulted from these causes (Art. 552/1). Termination of pregnancy where the child has an incurable or serious deformity or where the pregnant woman, owing to a physical or mental deficiency, suffers from or her minority, is physically as well as mentally unfit to bring up the child are new defenses introduced by the 2004 Criminal Code, Art. 551(1) (c \&d). Moreover Article 550 allows mitigation of punishment for abortion done "on account of extreme poverty."

h) The Revised law has also done away with the formalities required for abortions performed for medical reasons and provides that the Ministry of health shall issue directives under which pregnancy may be terminated (Art. 552/1). Violation of such directives is made punishable by fine not exceeding one thousand Birr, or simple imprisonment not exceeding three months (Art. 552/2).

The new law has broadened the grounds of legal abortion and this is definitely a step forward. Articles 551 and 550 of the 2004 Criminal Code have thus elevated Ethiopia's position in the spectrum of Levels of Freedom of Abortion:

\section{Table II - Grounds on which abortion is permitted under the 2004 Criminal Code}

- To save the life of the woman...................

Yes (Art. 551/1/b)

- To preserve physical health....................

Yes (Art. 551/1/b)

- To preserve mental health......................

Yes (Art. 551/1/d)

• Rape or incest................................

Yes (Art. 551/1/a)

- Foetal impairment.

Yes (551/1 /c /b)

- Economic or social reasons

No*

- Available on request...........................

No

* The 2004 Criminal Code Considers 'extreme poverty' as a mitigating factor which is far below rendering it unpunishable. 
Minutes of the Justice System Reform Program Coordinating Committee indicate that a Policy Committee which consists of high ranking government officials and legal experts had decided by majority, in favour of decriminalizing abortion in 2003..$^{93}$ But, since the law could not be enacted - as expected at the end of the parliamentary year, it appears that the pro-life group seized this opportunity to push its views and the new law couldn't go beyond the Level shown in Table II above.

To sum up, it can be said that Ethiopian abortion law started its voyage from rigid restrictions to some reform in 1957, and it has indeed broadened the scope of permissible abortion under the 2004 Criminal Code although it has yet to elevate itself towards the level it deserves. Until the pro-choice stance of our laws become commensurate with our needs and the objective reality, the abortion is bound to continue underground thereby rendering the lives of pregnant women and girls susceptible to the dangers of unsafe abortion.

\section{The pro-life/pro-choice debate on the eve of the new Criminal Code}

The abortion issue has given rise to the emergence of two distinct groups with different positions. ${ }^{94}$ Both groups had campaigned to promote their respective positions by organizing workshops, street demonstrations, publication and other means. Given the history of Ethiopia, where laws are in most cases enacted without any ruffle, the campaigns of these groups were groundbreaking phenomena. The positions of these groups are presented as follows:

\section{1- The Anti-abortion group}

This group consisted of gynecologists, lawyers, and theologians. ${ }^{95}$ The group, in addition to staging street demonstrations against the draft law, published a material (62 pages) entitled: "The Bell of Death - Abortion and its Consequences”, on September 2003, in Amharic. The core contents of the material stated that:

a) Abortion is strictly forbidden in the Bible;

b) Women who abort suffer from different types of physical as well as psychological diseases, including cancer and are vulnerable to suicide;

\footnotetext{
${ }^{93}$ Minutes of the Justice System Reform Program Coordinating Committee (Sene 14, 1995 Eth. Cal., June 21, 2003) pp.3 \&4.

${ }^{94}$ Note - A draft law was initially prepared by the Ministry of Justice. Another draft was also prepared by the Justice and Legal System Research Institute. Both drafts have not, however, made radical changes on abortion.

The only case of departure was recognizing rape and incest as grounds of defense. The different lobbies were thus staged based on the positions of the draft laws.

${ }^{95}$ Note: Given the contents of their material, which cites the Bible but not the Quoran, it seems that Muslims were not part of this campaign.
} 
c) Researches made by the pro-choice groups do not cover the whole country, as a result of which the vast rural areas are left out from coverage; these researches have failed to show the whole picture and are made with a view to justifying the decriminalization of abortion.

d) In an opinion poll collected in June 2003, in Addis Ababa, among 1000 female respondents: $91 \%$ responded that abortion is not a solution to social problems, while $7 \%$ responded that it is; $80 \%$ responded that decriminalizing abortion is not an issue of the rights of Ethiopian women, while $17 \%$ responded that it is; $92 \%$ opposed the legalization of abortion, while $8 \%$ supported legalization;

e) By legalizing abortion on demand, Ethiopia will join the minority (27\%) of the international community, but not the majority;

f) The researches, which disclosed that the maternal mortality rate of the country is $50 \%$, were made before two decades (in 1983). In two researches published in 1988 and 1993, however, the rate is found to be $22 \%$ only;

g) Instances, which call for abortion to save the life of the pregnant woman, do not arise in practice.

Based on the premises here-in-above, the group recommended that:

a) individuals should abstain from sexual intercourse before marriage and extra marital sexual intercourse, after marriage;

b) women should be encouraged to make use of every variety of contraceptives, except loops, that adversely affect the foetus after conception;

c) women who are faced with pregnancies should be (persuaded?) to accept the situation, but be supported financially, materially, etc.

d) abortion should not be allowed even in cases of pregnancies resulting from rape or incest.

Although it is not clear whether it is a follow-up to the campaign by this lobby group, or that the Ethiopian Orthodox Church is part of this group, the Church made its position on abortion clear in a separate occasion, soon after the publication of the above discussed material. Accordingly, the Patriarch gave a press statement that was reported in Ethiopian Herald and Addis Zemen on December 25, 2003 (Tahsas, 15, 1996). The core contents of the statement underlined that:

"as humanity begins from birth, any attempt to or act of abortion is imperious and sacrilegious; abortion is inhuman and anti religious because it is an act of trespassing the laws of providence in creation in which parents serve the means of god's will; abortion is a contravention of the Devine command: "Thou shall [not] kill”; and the movement to make abortion legal only emanates from selfish and capricious motives.” 


\section{2- The Pro-choice Group}

Different groups advocated for the legalization of abortion. Given the efforts made in exposing the magnitude of abortion in Ethiopia, persistence in creating awareness among the public, methods and standards of articulating the issue, ESOG (Ethiopian Society of Obstetricians and Gynaecologists) stands first among all others. Believing that other groups also share ESOG's position, the latter's position alone is presented here-below: ${ }^{96}$

a) all data collected in the country indicate that abortion is the major cause of maternal mortality;

b) reproductive health rights are indivisible women's rights;

c) abortion is a multifaceted health, social, economic, psychological, and reproductive problem;

d) the position of the 1957 Penal Code has contradicted these rights and has greatly contributed to the above problems.

The Association, therefore, called for inter alia, the following:

a) women should be given the opportunity to terminate unwanted pregnancies;

b) abortion should be decriminalized;

c) abortion should be allowed when it is proved that the pregnancy jeopardizes the health and social life of the woman and the fetus, when pregnancy results from rape, or due to contraception failure;

d) abortion should be provided together with strong counseling; and

e) abortion should not, however, be taken as a major means of [family planning] and family planning services should be expanded.

\section{3- Public opinion during the Legislature's workshops and public meetings}

The Women's Affairs Committee and the Legal and Administration Affairs Standing Committee of the Legislature, had organized two workshops in November 1999 and March 2003, respectively, to discuss the draft criminal law. Abortion was one of the major issues that were deliberated in these workshops. Although no votes were taken during these deliberations, it was apparent that the general view leaned towards liberalization of the existing law. ${ }^{97}$ Almost all resource persons were pro-choice (or close to this view), though there were some participants who voiced anti-abortion views based on reli-

\footnotetext{
${ }^{95}$ Note. The following are major points in the position of the Association, and are taken from a leaflet flyer distributed at one of the workshops organized by IPAS, at the end of 2003. The leaflet is entitled as "ESOG's
Position on Abortion" (written in Amharic). ${ }^{97}$ Note. This writer was one of the resource persons in these workshops, and this asser- tion is made based on this personal experi- ence.


gious grounds. Resource persons were drawn mainly from two professions, namely law and medicine. The presentations and the discussions addressed the magnitude of the problem of abortion in Ethiopia and the legal issue of abortion in light of the Constitution and laws of other countries.

The following provisions of the Constitution of the Federal Democratic Republic of Ethiopia (Proclamation No.1/1995) were invoked during the workshops:

\section{Art.35. Rights of Women}

(4) The State shall enforce the right of women to eliminate the influences of harmful customs. Laws, customs, and practices that oppress or cause bodily or mental harm to women are prohibited.

(9) To prevent harm arising from pregnancy and childbirth and in order to safeguard their health, women have the right of access to family planning education, information, and capacity.

It was also argued that the constitutional right to privacy, which is enshrined under Article 26 of the Constitution, should be interpreted in line with the decision in the case of Roe $v$ Wade. The conclusion was, therefore, that the Ethiopian law of abortion (under the 1957 Penal Code) is unconstitutional.

Moreover, the Legislature had called public meetings at major cities ${ }^{98}$ of the country to discuss on the draft laws. Here again, abortion was one of the prominent issues that attracted public attention. Unpublished minutes of these meetings (written in Amharic) disclosed the following:

a) Although abortion was widely discussed in all the fourteen cities, votes on the issue were taken in five cities, only. Accordingly, despite the fact that these two cities have no particular culture of conservatism or the dominance of any one known religion, participants in Awasa and Dire Dawa voted against decriminalization of abortion. Interestingly enough, the same participants voted for the criminalization of prostitution, which is not a criminal act under the existing law.

b) Participants from Ambo, Dessie, and Adama voted in favour of the position of the draft law.

c) It appears that no votes were taken in the meetings held at Harrar, the minutes imply that the dominant position was allowing abortion on demand when pregnancy resulted from extra-marital relationships, provided that it does not endanger the mother and allow the act in a restrictive manner, and in case when the pregnancy is the result of marital union.

${ }^{98}$ These cities are: Jijiga, Awasa. Harrar, Assosa, Desse, Arba Minch, Assayita, Nekemte, Mekelle, Adama, Dire Dawa, Bahr Dar, Gambella, and Addis Ababa. 
d) In all other places, namely Jijiga, Assosa, Arba Minch, Assayita, Nekemte, Mekelle, Bahr Dar, and Gambella, the issue was adequately discussed although no votes were taken. ${ }^{99}$

\section{Concluding remarks}

As Donald Judges correctly remarked:

Abortion is an exceptionally serious decision for most women, arrived at after weighing numerous important considerations - many of which involve balancing a variety of responsibilities...people should, [therefore], be careful in judging a decision they have not personally faced. ${ }^{100}$

The root cause of induced abortion is, no doubt, unwanted pregnancy. It also goes without saying that unwanted pregnancy occurs more frequently in modern societies than the old, for at present there are more reasons to postpone one's marriage than in the past. Pursuing one's education, waiting to have certain material possessions, looking for a proper partner, etc. which were not significant causes in the past, may force one to postpone his/ her marriage and engage in pre-marital intimate relations. Moreover, even in marriage, contraception failure, rape or incest can bring about unwanted pregnancy. Biological grounds, such as inability to carry the pregnancy are also causes of induced abortion. Given the multiplicity of causes, a law that attempts to spare pregnant women from the unwanted consequences of illegal abortion, should at the same time address the root causes, without which legal condemnation alone will not bear fruit.

Apart from adverse factors such as inaccessibility of health facilities, restrictive laws have contributed to the sad predicament of those women that seek abortion. Apparently, the dire consequences of illegal abortion are nearly nonexistent in countries with liberal abortion laws while the reverse is the case in those countries that have restrictive laws.

Ethiopian abortion laws have to a certain extent reacted to the social dynamism that calls for change. Although, the researches made in the field show that illegal abortion has resulted in dire consequences than anywhere in the world, it may, however, be presumed that the researches merely indicate the tip of an iceberg. This is so, because many women still do not have access to medical care and abortion can be procured in sophisticated health facilities that can perform the procedure without a hitch. The data in every research

\footnotetext{
${ }^{99}$ Note. The points contained in these minutes are somewhat confusing and vague. Accordingly, in those places where participants voted for decriminalizing abortion, it

is not clear whether they voted to retain the position of the existing law or that the act should be criminalized in toto.

${ }^{100}$ Judges, Supra, Note 2. at 33
} 
cannot thus capture the real figures of actual abortions. Nor can the extent of abortion and its adverse consequences be captured through data gathered by researchers.

Be this as it may, it will be imperative to ask whether the new law has addressed the issue adequately. In the opinion of this writer, the new law still seems to be half baked. Needless-to-say, the law does not recognize contraception failure, the number of children in a family, HIV/AIDS, and the predicaments of the unmarried and prostitutes as justification for legal abortion. Failure to take such social and economic factors into account is clearly among the major shortcomings of the 2004 Revised Criminal Code.

Although the new law has introduced a major shift, it still needs to adjust itself to the reality and allow abortion for every justifiable ground. Given the fact that a woman bent on aborting a fetus cannot be deterred by any sanction of the law, allowing abortion on demand is the only realistic option. Since the law does not address the above mentioned causes of unwanted pregnancy and others, it is currently susceptible to widespread violations through underground abortions.

Soon after the enactment of the law, the Ministry of Health issued "Technical and Procedural Guidelines for Safe Abortion in Ethiopia” in June 2006. The Guidelines, inter alia, provide that:

"abortion is the termination of pregnancy before fetal viability, which is conventionally taken to be less than 28 weeks from the last menstrual period or if this is not known, a birth weight of less than 1000 gm.; the woman seeking the service is entitled to have it within three working days, after counseling, and minors and mentally disabled women should not be required to sign a consent form to obtain the procedure.”

It might take some time for Ethiopian abortion law to take another courageous step towards legalizing abortion on social and economic grounds. It might even take longer to allow abortion on request. Meanwhile, however, the issuance of the Technical and Procedural Guidelines for Safe Abortion by the Ministry of Health, at the heel of the new law is indeed encouraging. The Ministry is thus expected to make every needy woman the beneficiary of the new change; and it may be hoped that Ethiopian women will be spared from the unwanted and remediable consequences of unsafe abortion in the near future. 